\title{
Inclusive partnership: Enhancing Student Engagement in Geography
}

* Moore-Cherry, N., School of Geography, Planning and Environmental Policy / Earth Institute, University College Dublin, Ireland, niamh.moore@ucd.ie

Healey, R., Department of Geography and Development Studies, University of Chester

Andrews, W., Department of Geography and Earth Sciences, Aberystwyth University

Nicholson, D. T., Geography and Environmental Management, School of Science and the Environment, Manchester Metropolitan University

* Corresponding author 


\begin{abstract}
Partnership is currently the focus of much work within higher education (HEA, 2014; Healey et al., 2014; Cook-Sather et al., 2014) and advocated as an important process to address a range of higher education goals. In this paper, we propose the term inclusive partnership to conceptualise a non-selective staff-student relationship. While recognising the challenges of inclusive partnership working for institutions, staff and students, this paper outlines the opportunities it offers and provides detailed case studies of inclusive partnerships within the geography curriculum. We conclude with some guiding principles to inform the development of inclusive partnerships in a range of settings.
\end{abstract}

Keywords: partnership, inclusive partnership, student engagement, belonging, academic identity, student confidence 


\section{Introduction}

"All partnership is student engagement, but not all student engagement is partnership" (Healey et al., 2014: 15)

Partnership can be defined as the engagement of a range of stakeholders with each other to achieve a common goal (HEA, 2014). In recent years, partnership has been the focus of much work in higher education (Bovill et al., 2011; Healey et al., 2014). Given the many demands on higher education institutions, working in partnership has the potential to contribute to a range of goals including the development of graduate attributes, improving staff-student relationships, enhancing employability, adopting more scholarly approaches to teaching, student learning and engagement (Bovill et al., in review).

Healey et al. (2014) suggest the need to consider partnership as a process that engages students more fully with their institution and their own learning. Partnership is not an outcome to be aspired to but a way of working, usually with specific student groups, that achieves broader objectives. In this paper, we propose the term inclusive partnership to conceptualize a relationship that facilitates better and more meaningful engagement of all students through empowerment and confidence building. The ultimate goal is to develop a better sense of belonging to the broader community of scholarly education (Felten et al., 2013). Inclusive partnership is an ideal to strive for but whether or not it is achievable as a process is dependent on the institutional context and other challenges, discussed in section 4 . While we recognize that partnerships can take many forms and include a range of different stakeholders, our focus is on the type of partnerships formed between academics and students within the framework of the formal curriculum. The concept of inclusive partnership has broad applicability across disciplines, but we suggest that the diversity of learning spaces geographers occupy (see Hill et al., under review) provides particular opportunities to engage in inclusive partnership working. While we acknowledge the specific challenges faced by academic staff who wish to develop these kinds of working relationships, such as the renegotiation of power relationships and perception of additional time commitments required, we focus on the significant opportunities they present to develop more democratic and inclusive learning environments. We suggest that the facilitation of inclusive partnerships is possible throughout the geography curriculum and, in section 3, provide detailed case studies to illustrate inclusive partnerships in practice from first year induction through to Masters programmes in geography. We conclude by suggesting some guiding principles for inclusive partnership working in geography.

\section{Inclusive partnership: belonging, confidence and engagement}

\subsection{Partnership}

Following Healey et al. (2014), our working definition of partnership is not tightly-constrained, rather it seeks to indicate boundaries to the concept. At first glance, partnership appears to be a relatively simple concept whereby colleagues or associates "work or play together" (Webster, 1996: 859). As the opening quote suggests, it is important to recognise the distinctive characteristics of partnership as a particular type of engagement. Engagement focuses on students' practical actions in terms of their own welfare and learning within a given system or institution, and the ways that these actions contribute to positive outcomes (Kuh et al., 2008). However, partnership

goes far beyond the mere consultation, involvement, or representation of students in decision-making. Where partnership exists, students not only identify areas for 
enhancement, but they help to identify ways to carry out that enhancement, as well as helping to facilitate implementation where possible (Williamson, 2013: 8).

Students may be consulted, involved, participate or be partners in their learning (Healey et al., 2014) and each are qualitatively different forms of student engagement. What characterises partnership is the involvement of students with both the process and the outcome and the sharing of the risk and the rewards of the endeavour between all parties (HEA and NUS, 2011). This brings us closer to a useful definition for the higher education context where partnership is recognised as a process (Healey et al., 2014) that develops as part of the ethos of the institution rather than an activity in itself (NUS, 2012). As with all definitions of the concept, a sense of support and collaboration remains integral but this is institutionally grounded by the creation of conditions that enable collaborative working relationships.

Partnerships occur at both the individual and institutional level and may embrace a diversity of stakeholders. These can develop in various contexts (HEA, 2014) between:

- students and staff (tutors, library, student support services etc.)

- staff and staff (co-teaching, peer review of teaching)

- students and students (peer-. mentoring, equal, longitudinal etc.)

- students and institution (external examiners, programme review, staff-student liaison committee, ambassador programmes etc.)

- students and the student union (their representative body)

- students and external bodies (employers, Professional Statutory Regulatory Bodies, outreach, public engagement, voluntary organisations etc.)

These partnerships have the common goal of enhancing learning and teaching in higher education, yet the extent to which partnerships may develop are determined by the institutional context (Whitt et al., 2008). Several attempts have been made to identify the principles of effective partnership (Schroeder et al., 1999; Whitt et al., 2008; HEA, 2014; Healey et al., 2014). The common features of these are a shared vision, empowerment, organisation, authenticity, and challenge (Cook-Sather et al., 2014). Partnership working empowers students to engage and develop a clear sense that they belong to a bigger learning community. The learning community encompasses the multiple scales at which a student is engaged, for example the module, the programme/course and more broadly the institution, and the discipline. If a student is fully engaged, this should be evident at multiple levels and scales concurrently. Critical to achieving this engagement is for students to feel that they belong to their learning community (Tinto, 2005). It is a

students' sense of being accepted, valued, included, and encouraged by others (teacher and peers) in the academic classroom setting and of feeling oneself to be an important part of the life and activity of the class. More than simple perceived liking or warmth, it also involves support and respect for personal autonomy and for the student as an individual (Goodenow, 1993: 25).

This definition draws together the individual and the institutional, students and staff, support and autonomy, within a mutually respectful setting. This 'sense of belonging and intimacy' plays an important role in retention and engagement (Cashmore et al. 2007), an important indicator of integration, itself a powerful predictor of completion and achievement (Kember $e t$ $a l ., 2001)$. Thomas (2012: 7) suggests that

... student belonging is achieved through supportive peer relations, meaningful interaction between staff and students, developing knowledge, confidence and identity 
as successful HE learners, [and] an HE experience relevant to students' interests and future goals.

This sense of belonging is collectively produced, for while "belonging is a subjective feeling held by individuals, it is also socially defined" (Ralph and Staeheli, 2011: 523). Social (institutional) structures define who belongs, where and on what basis.

It is within these structures that partnerships are formed. Partnerships commonly develop when some form of selection takes place, either by the students themselves volunteering to work on a project (see for example a community flood resilience and science education project, described in Klein et al., 2011) or following selection by their tutors. Some examples of successful partnership working within geography curricula include internships / placements as a formal part of the curriculum (Healey et al., 2014), the development of co-curricular field trips (Schroeder et al., 1999) and the engagement of geography students with community groups in research-oriented projects (Bednarz et al., 2008). While these are demonstrably important learning experiences for those involved, these types of partnerships are not always available to, or beneficial for, all students. Here the social context empowers selected students building their confidence and their sense of belonging (Figure 1). While worthwhile, the impact is limited to those who have privileged access to the learning partnership with non-selected students feeling less embedded within the learning community. In this paper, we propose a more broad-based form of inclusive partnership involving all students to generate a more sustained, inclusive and engaged community of scholarly education.

\section{INSERT FIGURE 1 HERE}

\subsection{Inclusive practice}

Inclusive learning and teaching in higher education refers to the ways in which pedagogy, curricula and assessment are designed and delivered to engage students in learning that is meaningful, relevant and accessible to all. It embraces a view of the individual and individual difference as the source of diversity that can enrich the lives and learning of others (Hockings, 2010: 1).

In this context, diversity is understood well beyond the Protected Characteristics embodied legislatively in many countries through instruments such as the Equal Status Acts, 2000-2008 in Ireland, Equality Act, 2010 (UK) and a similarly named Act in the United States. Inclusive learning and teaching embraces diversity in education (e.g. entry qualifications, skills and knowledge, approaches to learning), disposition (e.g. identity, self-esteem, motivation, aspirations, interests, gender, sexuality), circumstances (e.g. age, disability, access to IT and transport services, financial background), and culture (e.g. language, values, religion and belief) (Thomas and May, 2010). Our concept of inclusivity and diversity considers not only these individual characteristics, but also importantly how these intersect.

Underpinning the concept of inclusive learning and teaching are values of equity and fairness. This means taking account of and valuing students' differences within mainstream curriculum, pedagogy and assessment (Table 1) with the ultimate goal of enhancing engagement. The ultimate objective of inclusive practice is to remove barriers to any individual or group achieving their full potential by developing a general sense of belonging within and identity with the institution, and promoting a respectful working atmosphere that celebrates diversity, engaging students as effectively as possible with their own learning and teaching experiences. We argue that partnership working can provide a process through which inclusive practice can 
be embedded and offer the term inclusive partnership to encapsulate the mainstreaming of the concept.

\section{INSERT TABLE 1 HERE}

\subsection{Inclusive partnerships}

While all-embracing, inclusive practice does not necessitate a loss of individual identity, nor does it guarantee that all individual needs will be met (Hockings, 2010). It does, however, attempt to create the conditions within which all students will feel an enhanced sense of belonging. We argue that adopting more inclusive learning and teaching practices can play a significant role in building academic identity and an enhanced sense of belonging within their higher education institutions especially for early stage students. Whilst 'inclusive partnership' is a process to promote the development of a more engaged community of scholarly education, it is important to recognise that transition to such a learning community may never be finished or achieved in full because it is always in process (NUS, 2012: 11). In Table 2 we highlight the differences and similarities between partnership and inclusive partnership.

\section{INSERT TABLE 2 HERE}

Inclusive partnership working challenges staff to go beyond just working with the 'usual suspects' who self-select and volunteer to participate in various activities and requires a reconceptualisation of the learning and working environment experienced by all students. In order for the general student body to engage in partner relationships it is necessary that the social structures within higher education are collectively altered to re-define the spaces students occupy and on what basis. Ignatieff (1994: 25) argues that "where you belong is where you are safe; and where you are safe is where you belong". An inclusive partnership approach would, in an ideal scenario (Figure 2 - right hand side), celebrate the potential of diversity broadlydefined to enrich learning, to foster a student's security within their learning environments, thereby developing their sense of place within the learning community. This confidence (at both a personal and institutional level) is vitally important in enhancing student engagement, retention and success and giving them a sense of ownership of their own learning. It can be expressed in terms of students knowing what is expected of them (by themselves and by external agents), what they feel able to achieve, and the skills or competencies that are provided by their university experience as a whole (Thomas, 2013). Inclusive partnerships engage staff and students in a more dialogical and iterative relationship facilitating these dialogues as a regular part of the learning cycle, building confidence to participate and engage in a range of different ways. The trust and respect developed contributes to the formation of a much clearer academic identity for students and building a positive feedback loop as confidence is reinforced.

\section{INSERT FIGURE 2 HERE}

As confidence builds students become more able to take responsibility and ownership of their learning and begin to form their academic identity. Figure 2 conceptualises how confidence, responsibility and ownership, trust and respect, support one another to form a student's academic identity and develop a student's sense of belonging to an institution. Within our model the entire student body has the potential for enhanced engagement contributing to a more diverse and inclusive multi-scalar learning community. 


\subsection{Inclusive partnerships in geography}

This democratisation of the learning process is challenging but in many geography programmes this type of working relationship often already exists, perhaps in a more informal and temporally-constrained way, in particular learning spaces. Field courses for example are cited as important vehicles through which student interest is stimulated and collaborative learning occurs (Fuller et al., 2014; Nicholson, 2011). The value of residential fieldwork in particular, in reinforcing learning through "less formal lecturer - student and student - student interactions" (Fuller et al., 2006: 94) can provide the seedbed for disrupting traditional academic power relations. However, inclusive partnership opportunities in geography are not just restricted to field-based learning. Opportunities to embed inclusive partnership arise in a wide range of learning contexts in geography (Table 3). These may be primarily related to the physical learning space (e.g. field class, laboratory activity, online learning environment), the type of learning activity involved (e.g. assessment, undergraduate research, professional development), or the nature of the relationship between participants (e.g. peer mentors, project supervision, collaborative enquiry).

\section{Inclusive partnerships in practice}

As Table 3 illustrates, the opportunities to develop inclusive partnerships with students are many but they can be challenging for both staff and students. Nonetheless, as the case studies below illustrate, effective inclusive partnership approaches can be developed with students at different stages in their education to build many of the attributes considered fundamental to full participation within the learning community. The case studies below illustrate the diverse nature that inclusive partnerships can take - in terms of stage in the curriculum, the identity of the partners and the actual partnership activities - but also highlight how the key underlying principles outlined in Table 2 can be operationalised in practice.

\section{Case Study 1: Building geographical identity, First year undergraduate environmental and geographical sciences, Manchester Metropolitan University}

Around 150-200 students participate in the Collaborative Induction Project (CIP) during an extended (two week) induction period that embeds the ethos of inclusive partnership across the entire Environmental and Geographical Sciences Programme (Geography, Human Geography, Physical Geography, Environmental Science, Environment, Management and Sustainability, and Ecology and Conservation.

Students work in same-subject teams of five to prepare a pitch for an episode of a new, hypothetical BBC environment-focussed documentary series. The CIP, supported by a handbook, takes place over six working days during induction, beginning with a morning spent introducing the project. Two tutors, with disciplines matched to student groups, are allocated as advisors for each cohort of around 25 students. Their role is advisory, and staff are primed to encourage students to develop and build their own ideas, thus empowering students, and working to a common purpose.

The activity has four aims: 1) To rapidly engage students in topics relevant to their degree courses, to enthuse them about their discipline and help them begin to identify their own areas of interest. Thus the project is relevant, real-world, and facilitates a sense of belonging to the broader discipline of geography. 2) To provide opportunities for students to make friends, bond with others in their cohort, break down barriers and power relations (including staff) across different backgrounds, skills and abilities. 3) To support students in early skills development 
and confidence building by providing an organised programme of classes and supporting documents. 4) To help students discover that learning can be challenging, fun, motivating, inspirational, and relevant.

Early support is provided through a colloquium in which tutors, selected for their engaged approach, inspire students with project ideas, often building on their own scholarly interests. During subsequent team-working activities, the dynamics and mechanics of collaborative work are specifically addressed. This encourages students to consider their own learning styles, the roles, experiences, talents of team members, and how to best utilise these, thus creating an openness and celebration around diversity. Student confidence is built upon by supporting skills development through training in the use of online and University electronic and library resources, including a fun but challenging, self-managed library treasure hunt. An interactive class on constructing an argument promotes participation as individuals, in pairs, groups, or through the use of post-it notes (or in-class response systems to encourage even fuller participation). Further support is provided through an ideas factory on presentation ideas, delivered using Prezi, and aimed at encouraging students to think creatively, and 'outside the box'. The success of the project is evident from the variety of creative pitches that have been presented in the past (e.g. physical models, public inquiry style debates, role play, posters and displays, audience participation events, and the use of Prezi or PowerPoint to display groupcreated blogs, web pages, YouTube content, Twitter feeds and Facebook pages).

The choice available encourages students to play to their strengths, unconstrained by more traditional styles of assessment. The formative nature of the project creates a non-threatening learning environment in which students can experiment, explore their own identity as learners, as Geographers, as students in higher education, and as individuals within broader society.

\section{Case study 2: Enhancing ownership and student autonomy, Second year Geography, University of Chester, England}

The second year tutorials module for Single Honours or Geography Majors comprises of small tutorial groups of 6-7 students formed at the start of the year. These meet every two weeks offering regular and effective tutor-student communications. Students are provided with a brief in advance of each tutorial and are then assessed at each tutorial using detailed marking criteria. In 2010-11 a new ethical scenarios strand was introduced to support students to develop ethical thinking skills. Students were provided with an ethical scenario every two weeks to consider and decide on the course of action that they would take. In 2013-14 the 'ethical thinking' strand developed further with the introduction of a new brief that asked students to write their own ethical scenario for discussion within their groups. 44 students took the module in 2013-14.

The purpose of this activity was threefold: 1) It supported students to identify an ethical problem by asking them to write a scenario using real-life contexts that had an undesirable impact on something and/or someone else; and caused conflict between two or more of their values and beliefs; 2) It provided students with ownership over their work and the discussion by allowing them to decide what their scenario should focus on and how this was discussed with their peers; 3) Students learnt from resources produced by other students which also saves tutor time spent on producing ethical scenarios.

To begin with it was necessary to build confidence in order for students to feel comfortable producing their own scenario. This was achieved by providing students in the early part of the module with tutor-produced scenarios that could be used as a basis for their own work. Opportunities were provided to discuss these scenarios, considering what they believed to be 
an ethical problem and explaining and justifying how they would respond in the described situation. Supportive feedback was provided during these discussions from both peers and tutors. As the scenario strand developed the ethical problems became more complex. After the $8^{\text {th }}$ scenario, students were asked to produce their own scenario. This empowered the students by giving them autonomy and responsibility to produce resources for other students to learn from. This activity provided them with a deeper learning experience as they had to apply what they had learnt through the earlier scenarios to produce their own. The subsequent discussions of the scenarios enabled a collaborative group learning experience as students considered what they would do in the different scenarios presented.

Student production of scenarios was challenging. It required students to take risks and share what they considered to be an ethical problem with their peers and a staff member. They were supported in taking risks through the development of trust amongst their tutorial groups, having previously met with them fortnightly over a 6-month period. The level of trust developed and mutual respect was illustrated in the scenarios produced, many of which related to the students' current anxieties in their studies. The opportunity to produce materials and lead the discussion around that scenario placed the student in a position traditionally held by academic members of staff, therefore supporting them to develop their academic identity as partners in their learning and creating an expectation of success for all.

\section{Case study 3: Cultivating belonging to a community of geographic enquiry, Second year and MA Geography, University College Dublin, Ireland}

Geographic Research Techniques is delivered as part of the second year geography curriculum and taken by approximately 280 students each year. Simultaneously, as part of the MA Geography programme students are required to take a more advanced skills module, delivered by the same staff member, that also involves fieldwork and independent research. Similar to some of the examples in Table 3 above, this case study illustrates how different cohorts of students can partner each other and staff through a particular programme of work.

The purpose of this activity was: 1) to enhance the research identity of undergraduate students within a research-intensive university, 2) to build a sense of belonging to a wider learning community of geographic enquiry, 3) to develop competence in investigating real-world problems and 4) to challenge students to think beyond their immediate programme to the wider relevance of their studies.

The thirteen students who comprised the MA cohort were broken into groups of three and four and asked, as part of their assessment, to design a fieldtrip for second year students around Dublin city on a specified theme. The geographical, thematic and temporal scope of the project was clearly outlined but the students were given flexibility to design a fieldtrip route and research activity of their choice to assign the second year class. Regular communication between the Masters group and the staff member was maintained through in-class open discussions and informal meetings. The groups of Masters students orally presented their fieldtrip proposals to the second year cohort. The undergraduate students were given the choice of fieldtrip that they felt was most relevant to them based on their intrinsic preferences. The MA student groups then collaborated with the second year students in the field, advising them on their research activity as it unfolded, empowering both cohorts and allowing them to cocreate their learning experiences in a supportive and friendly environment. The level of guidance and support given to the second years by the postgraduates saved the module coordinator significant time that would otherwise have been spent in feedback sessions. The students and the staff member shared a common purpose as the students were collaboratively learning new skills and developing a sense of being part of a common community of learning. 
This activity was challenging for both groups. In particular, the second year students had a mixed response with some excited that "They [the MA students] might have a good idea about what would interest us" while others considered it "a cop-out. Masters students are only two years out from us." This illustrates the challenge of engaging in inclusive partnerships as it involved risk taking and the negotiation of competing perspectives. However, the MA students quickly recognised the shared risks and rewards of an inclusive partnership approach suggesting that it "develops both the student academically and indeed gives the lecturer new ideas" while involving "significant increased responsibility". Key outcomes were: 1) a sense of empowerment for the Masters students as they assumed significant responsibility for the wider groups learning; 2) challenging the undergraduate students conventional views of themselves as subordinates and the module coordinator as expert and 3) the development of an awareness among both cohorts that they are parts of a wider scholarly community of geographers.

\section{Discussion}

Our case studies from specific geography programmes and our general discussion have illustrated how inclusive partnerships demand a reconsideration of the learning process by all stakeholders to ensure shared expectations and understanding. As suggested earlier in the paper, there are some challenges to moving towards more inclusive partnership working. Firstly, institutional regulations and norms are crucial to shaping the learning environment. Navigating institutional structures that may favour the adoption of more traditional expert/novice type approaches to learning can be a significant impediment to the development of partnership working (Bovill et al., in review). While this can be relatively easily overcome or at least negotiated informally in small groups where students either elect or are chosen to participate, it becomes a major challenge for inclusive partnerships involving courses with large numbers of students. From an institutional perspective, promoting partnership with large classes may challenge existing norms around, for example, assessment protocols or regulatory approvals as it fundamentally disrupts existing, often hierarchical, power relations within the institution.

Secondly, inclusive partnership working demands greater 'vertical integration' challenging staff to redress power relations at the classroom scale (NUS, 2012: 3). While time is often cited as a challenge in undertaking such changes, we argue that inclusive partnership working requires a different kind of, rather than more, working. This moves students from being passive recipients or consumers of knowledge within a traditional hierarchical structure (Bovill et al., 2011: 1) to being active or interactive participants in the development of their own learning communities (Healey, et al., 2014: 7; NUS, 2012: 2). For many staff, this can be daunting as it can require changing deeply entrenched mindsets. For students, this way of working challenges them to take greater responsibility and ownership of their experience becoming less of a consumer and more of a co-producer of knowledge (McCulloch, 2009). Although key to the concept of 'inclusive partnership' is that students themselves are recognised as a valuable resource, students may feel they do not have the skills or competency to engage effectively with staff in this learning journey. Central to building confidence is the understanding that the risks and rewards are shared and this may demand a diversity of stages and student appropriate partnership practices at different junctures in the curriculum, as discussed below.

In our case studies, the demands placed on the students in their first year group exercise was, for example, entirely different from that placed on the Masters students who were required to assume much more power and responsibility within the partnership. While many students comment on the rewards of inclusive partnership working, there may be other points in the student life-cycle where the risks associated with this kind of activity are considered too high relative to the potential rewards. For example, in many undergraduate degrees the relative 
weighting of assessment increases towards the end of the programme, consequently in the final degree year students often become much more focused on 'hard' learning outcomes (results, grades, portfolio) rather than being open to enhancing 'soft' learning outcomes (skills, creativity). There may be an argument for front-loading inclusive partnership working early in the student lifecycle to engage them early and quickly, and build the confidence that will enable them to be more autonomous members of the learning community in later years. Inclusive partnership working may also challenge staff and students in new ways. For example, where there are students from diverse cultural backgrounds in a class - who may be used to more hierarchical learning and teaching - it may be necessary to modify the partnership process to ensure they are fully included in the learning community.

Having recognised these challenges, we would however argue that geographers regularly engage in pedagogical practices that go some way towards addressing them and embedding the key principles of partnership in their activities. In recent years, enquiry-based learning (EBL) has become a widely adopted practice within geography curricula. As a pedagogical approach, EBL challenges traditional student/lecturer identities and demands reflexive thinking. Thus we would argue that EBL modules may be useful seedbeds for fostering and maintaining the power transitions necessary for effective inclusive partnership to develop. Similarly, Marvell et al. (2013) highlight the potential of student-led teaching and learning during fieldwork to challenge the power relationship between student and tutor. The flexibility, organisation and shared vision required to successfully engage in fieldwork suggests this learning space as an ideal location within which inclusive partnerships could be relatively easily fostered.

While there may be justified concerns among staff in terms of managing partnership working with large student numbers, there is evidence that technology can be effectively harnessed to manage innovative pedagogical approaches with large class sizes (Moore \& Gilmartin, 2010). While virtual learning environments (VLE's) may in some cases be associated with a positivist pedagogy, if utilised correctly, they can be a tool to facilitate inclusive partnership working. Online environments can be a signficant aid in breaking traditional power relations and "supporting the participatory/transaction models of learning ... and ... a more androgogic, social constructivist pedagogy" (Jefferies et al., 2006, p. 437). The myriad tools and resources available through VLE's can support a diversity of student learning styles and preferences, providing an opportunity to engage as many students as possible with a particular topic or course of study while also facilitating the co-production of resources, ideas and activities by students themselves. These technologies can also potentially be used to enable staff and students to use their time more effectively.

For inclusive partnership to be effectively embedded in geography teaching and learning, we suggest the following guiding principles:

- Introduce inclusive partnership early as a way of working and learning to build student confidence and their sense of academic identity as a geographer.

- Use existing EBL and fieldwork modules as potential foundations for inclusive partnership working.

- Consider adopting less rigid interpretations of current institutional and regulatory constraints on curriculum design, delivery and assessment.

- Engage current student cohorts in assessing potential opportunities for future partnership.

- Open communication with a broad range of stakeholders - other staff, students, administrators, external - from your initial idea to develop a shared vision and buy-in to what the inclusive partnership is seeking to achieve and its potential impact for the wider geographic community. 
- Engage in significant forward-planning - developing facilitative institutional structures and ethos - to ensure that the partnership is as organised and systematic as possible. The types of risk assessment exercises undertaken in geography fieldwork might be a useful planning framework.

- Maintain flexibility not just in the operation of partnership but also the unexpected potential outcomes of the process.

\section{Conclusion}

In line with paradigm changes in the broader social sciences, partnership has recently become the focus of much interest within higher education. Following Healey et al. (2014), partnership is now conceptualised as a process of working rather than an outcome in itself and in this paper, we have introduced the term inclusive partnership to conceptualise partnership working with the wider student body rather than select cohorts. We argue that inclusive partnership is an ideal that all institutions should strive towards and, as our examples and case studies illustrate, it is possible to achieve in practice. However as discussed earlier there are institutional, personal and logistical challenges that must be met to adopt inclusive partnership working across the curriculum. It can be complex involving peer-to-peer as well as student-staff relationship building, and there may be particular junctures where it is more effective as a mechanism for building broad-based and sustained student engagement. There is a pragmatic argument for starting small at the level of the module or a piece of assessment - with the small things that are relatively easily changed -, hoping for spin-off effects and eventually the embedding of inclusive partnership working across the curriculum as part of broader institutional goals. While our focus has primarily been on the geography curriculum, we argue that developing inclusive partnerships in any curricula, particularly in the early stages could be pivotal in disrupting "automatically assumed" power relations and we have offered a number of guiding principles in this regard. 


\section{References}

Bednarz, S. W., Chalkley, B., Fletcher, S., Hay, I., Heron, E. L., Mohan, A., \& Trafford, J. (2008). Community engagement for student learning in geography. Journal of Geography in Higher Education, 32(1), 87-100.

Bovill, C. , Cook-Sather, A., Felten, P., Millard, L. and Moore-Cherry, N. (under review) "Addressing potential challenges in co-creating learning and teaching", Submitted to Higher Education.

Bovill, C., A. Cook-Sather and P. Felten. (2011) "Students as Co-Creators of Teaching Approaches, Course Design and Curricula: Implications for Academic Developers." International Journal for Academic Development 16 (2): 133-145.

Burgstahler, S. (2007). Equal Access: Universal Design of Instruction. University of Washington, Seattle. Available online http://www.washington.edu/doit/Brochures/Academics/equal_access_udi.html Accessed $17^{\text {th }}$ November 2014.

Cashmore, A., Scott, J., Cane, C., Bartle, C., Dorum, K., Jackson, P. and Pennington, M. (2007) '"Belonging" and "intimacy" factors in the retention of students-an investigation into the student perceptions of effective practice and how that practice can be replicated.'

https://www.heacademy.ac.uk/sites/default/files/Leicester_What_Works_Final_Report. pdf. Accessed $17^{\text {th }}$ November 2014

Coe, N. M. and Smyth, F. M. 2010. Students as tour guides: Innovation in fieldwork assessment. Journal of Geography in Higher Education 34(1), 125-139.

Cook-Sather, A., Bovill, C. and Felten, P. (2014) Engaging Students as Partners in Learning and Teaching: A Guide for Faculty. San Francisco: Jossey-Bass.

Felten, P., Bagg, J., Bumbry, M., Hill, J., Hornsby, K., Pratt, M. and Weller, S. (2013) A call for expanding inclusive student engagement in SoTL. Teaching and Learning Inquiry, $1(2), 63-74$.

Fuller, I. C., Mellor, A., \& Entwistle, J. A. (2014). Combining research-based student fieldwork with staff research to reinforce teaching and learning. Journal of Geography in Higher Education, 38(3), 383-400.

Fuller, I., Edmondson, S., France, D., Higgitt, D., \& Ratinen, I. (2006). International perspectives on the effectiveness of geography fieldwork for learning. Journal of Geography in Higher Education, 30(1), 89-101.

Goodenow, C. (1993). Classroom belonging among early adolescent students: Relationships to motivation and achievement. The Journal of Early Adolescence, 13: 21-43.

HEA (2014) Framework for Partnership in Learning and Teaching (Higher Education Academy), Available from: www.heacademy.ac.uk/students-as-partners. Accessed $17^{\text {th }}$ November 2014.

HEA and NUS (2011) Student Engagement Toolkit (Higher Education Academy and National Union of Students), Available from: 
http://www.nusconnect.org.uk/campaigns/highereducation/student-engagement/toolkit/ Accessed $17^{\text {th }}$ November 2014.

Healey, M., Flint, A. and Harrington, K. (2014) Engagement Through Partnership: Students as Partners in Learning and Teaching in Higher Education (HEA: York).

Hill, J., Thomas, G., Diaz, A. and Simm, D. (under review) Borderland Spaces for Learning Partnership: Opportunities, Benefits and Challenges, Journal of Geography in Higher Education.

Hill, J., Kneale, P., Nicholson, D. T., Waddington, S. and Ray, W. (2011) Re-framing the geography dissertation: a consideration of alternative, innovative and creative approaches. Journal of Geography in Higher Education. 35(3), 331-349.

Hockings, C. (2010) Inclusive Learning and Teaching in Higher Education: A Synthesis of Research. EvidenceNet, Higher Education Academy, 67pp.

Ignatieff, M. (1994) Blood and Belonging: Journeys into the New Nationalism, London: Vintage.

Jefferies, P., Stahl, B. C., \& McRobb, S. (2006). A Framework for Exploring the Relationships among Pedagogy, Ethics \&Technology. Advances in computer, information, and system sciences, and engineering, 433-440.

Kember, D., Lee, K. and Li, N. (2001) 'Cultivating a sense of belonging in part-time students.' International Journal of Lifelong Education, 20(4) pp. 326-341.

Klein, P., Fatima, M., McEwen, L., Moser, S. C., Schmidt, D., \& Zupan, S. (2011) "Dismantling the ivory tower: Engaging geographers in university-community partnerships." Journal of Geography in Higher Education, 35(3), 425-444.

Kuh, G. D., Cruce, T. M., Shoup, R., Kinzie, J. and Gonyea, R. M. (2008) 'Unmasking the effects of student engagement on first-year college grades and persistence.' The Journal of Higher Education, 79(5) pp. 540-563.

Mann, S. (2001). Alternative perspectives on the student experience: Alienation and engagement. Studies in Higher Education, 26, 1, 7-19.

Marvell, A., Simm, D., Schaaf, R., \& Harper, R. (2013). Students as scholars: evaluating student-led learning and teaching during fieldwork. Journal of Geography in Higher Education, 37(4), 547-566.

McCulloch, A. (2009). The student as co-producer: Learning from public administration about the student-university relationship. Studies in Higher Education, 34(2), 171-183.

Moore, N. and Gilmartin, M. (2010) Teaching for better learning: A blended learning pilot project with first year undergraduate students, Journal of Geography in Higher Education, 34(3), 327-344.

Nicholson, D. T. (2011). Embedding research in a field-based module through peer review and assessment for learning. Journal of Geography in Higher Education, 35(4), 529549.

Norsen, L., Opladen, J. and Quinn, J. (1995) Practice model: Collaborative practice, Critical Care Nursing Clinics of North America, 7 (1): 43-52. 
NUS (2011). Liberation, Equality and Diversity in the Curriculum. Online at: http://www.nusconnect.org.uk/news/article/6010/2523/

NUS (2012) A Manifesto for Partnership (National Union for Students: London), Available from: http://www.nusconnect.org.uk/resources/open/highereducation/A-Manifesto-forPartnership/ Accessed $17^{\text {th }}$ November 2014.

Ralph D. and Staeheli L.A. (2011) Home and migration: mobilities, belongings and identities. Geography Compass, 5 pp. 517-530.

Richardson, M. J. and Tate, S. 2013. Improving the transition to university: introducing student voices into the formal induction process for new geography undergraduates. Journal of Geography in Higher Education, 37 (4), 611-618.

Schroeder, C. C., Minor, F. D., and Tarkow, T. A. (1999) Learning communities: Partnerships between academic and student affairs. In J. H. Levine (ed.), Learning Communities: New Structures, New Partnerships for Learning. (National Resource Center for the First Year Experience and Students in Transition: Columbia, S.C.): 5969.

Skinner, E. 2007. Building knowledge and community through online discussion. Journal of Geography in Higher Education 31(3), 381-391.

Thomas, L. (2012). Building Student Engagement and Belonging in Higher Education at a Time of Change: A summary of findings and recommendations from the What Works? Student Retention and Success Programme. Paul Hamlyn Foundation, London.

Thomas, L. (2013) 'What works? Facilitating an effective transition into higher education.' Widening Participation and Lifelong Learning, 14(1) pp. 4-24.

Thomas, L. and May, H. (2010) Inclusive Learning and Teaching in Higher Education (Higher Education Academy: York).

Tinto, V. (2005) Taking student success seriously: Rethinking the first year of college.

Waterfield, J. and West, B. (2006) Inclusive Assessment in Higher Education: A Resource for Change, University of Plymouth: Plymouth.

Webster (1996) New World College Dictionary (3rd Edition). (New York: World).

Whitt, E.J., Nesheim, B.E., Guentzel, M.J., Kellogg, A.H., McDonald, W.M, Wells, C.A. (2008) 'Principles of good practice' for academic and student affairs partnership programs, Journal of College Student Development 49(3): 235-249.

Williamson, M. (2013) Guidance on the Development and Implementation of a Student Partnership Agreement in Universities (Sparqs: Edinburgh), Available at: http://www.sparqs.ac.uk/upfiles/Student\%20Partnership\%20Agreement\%20Guidance\% 20-\%20final\%20version.pdf Accessed $17^{\text {th }}$ November 2014. 


\begin{tabular}{|c|c|}
\hline Elements & Attributes \\
\hline Learning environment & $\begin{array}{l}\text { Welcoming, approachable and friendly tutors; promoting an expectation of mutual } \\
\text { respect; celebrating diversity; global citizenship and diversity awareness as taught } \\
\text { components; treating students as individuals; creating an expectation of success for } \\
\text { all. }\end{array}$ \\
\hline Communication & $\begin{array}{l}\text { Regular and effective tutor-student communication; opportunities for and training in } \\
\text { peer learning; communicating with clarity, coherence, appropriate volume and pace; } \\
\text { use of appropriate language (e.g. technical vocabulary, use of a glossary, avoidance } \\
\text { of colloquialisms and idioms, language structure, appropriate use of humour); } \\
\text { avoidance of stereotypes. }\end{array}$ \\
\hline Support & $\begin{array}{l}\text { Accessibility and approachability of tutors (e.g. patience, reliability openness, } \\
\text { empathy); availability of guidance (e.g. counselling, disability services, financial } \\
\text { advice); provision of study skills support; an open door policy. }\end{array}$ \\
\hline Teaching methods & $\begin{array}{l}\text { Use of variety in learning activities and media; interactivity; awareness of different } \\
\text { learning preferences (e.g. global-sequential); accessible and preparatory materials } \\
\text { (e.g. format, provision of materials in advance). }\end{array}$ \\
\hline Content and relevance & $\begin{array}{l}\text { Choice in curriculum content to maximise relevance; sensitivity and diversity } \\
\text { awareness in examples; relevance (e.g. contemporary, cultural links, student } \\
\text { aspirations, prior knowledge, life experience, real-world examples). }\end{array}$ \\
\hline Assessment & $\begin{array}{l}\text { Variety of assessment methods; choice in assessment (e.g. product and timing); } \\
\text { regular, timely and effective feedback; employment of good assessment design } \\
\text { principles (e.g. constructive alignment, clear expectations and assessment criteria); } \\
\text { and use of real-life contexts. }\end{array}$ \\
\hline Structure & $\begin{array}{l}\text { Module and programme flexibility (e.g. module structure, drop-ins, assessment } \\
\text { timing, progress reporting); build in classroom breaks (e.g. time out, rest breaks, time } \\
\text { to read, prior preparation time). }\end{array}$ \\
\hline Participation & $\begin{array}{l}\text { Encouraging full participation with a variety of non-intrusive methods (e.g. in-class } \\
\text { response systems, asynchronous chat, discussion boards, one-to-one, in-peer groups, } \\
\text { voting pods, open questions, group debate, whiteboards, post-it notes); collaborative } \\
\text { group work (e.g. clarifying and identify roles and expectations, establish ground } \\
\text { rules, teach diversity awareness as part of module content). }\end{array}$ \\
\hline Physical environment & $\begin{array}{l}\text { Accessible facilities, equipment and materials; appropriate room layout; comfort and } \\
\text { safety; use of technologies to enhance and facilitate choice and accessibility. }\end{array}$ \\
\hline
\end{tabular}

Table 1: Common elements of an inclusive curriculum (drawing on Waterfield and West, 2006; Burgstahler, 2007; NUS, 2011) 


\begin{tabular}{|c|c|c|}
\hline Principle & Partnership & Inclusive partnership \\
\hline $\begin{array}{l}\text { Develop a shared vision of } \\
\text { the desired outcome(s) } \\
\text { from partnership working }\end{array}$ & $\begin{array}{l}\text { Create a shared vision that is well } \\
\text { communicated between and } \\
\text { supported by all members (Norsen et } \\
\text { al., 1995; Schroeder et al., 1999; } \\
\text { Mann, 2001; Whitt } \text { et al., 2008; } \\
\text { Thomas and May, 2010). }\end{array}$ & $\begin{array}{l}\text { The shared vision should demonstrate a } \\
\text { clear awareness, celebration and } \\
\text { accommodation of educational, } \\
\text { circumstantial, disposition and cultural } \\
\text { diversity to be inclusive of all students. }\end{array}$ \\
\hline $\begin{array}{l}\text { Share power and } \\
\text { responsibility within the } \\
\text { partnership }\end{array}$ & $\begin{array}{l}\text { The selected students and staff should } \\
\text { negotiate the sharing of responsibility } \\
\text { and autonomy within the partnership } \\
\text { process for their mutual } \\
\text { benefit(Norsen } \text { et al., 1995; Mann, } \\
\text { 2001; HEA, 2014). }\end{array}$ & $\begin{array}{l}\text { Basic training in partnership working } \\
\text { may need to be initially provided to } \\
\text { ensure that all students feel empowered } \\
\text { to participate, and can better develop } \\
\text { their skills and enhance their confidence } \\
\text { to develop deeper learning. }\end{array}$ \\
\hline $\begin{array}{l}\text { Carefully manage and } \\
\text { monitor the operation of } \\
\text { the relationships }\end{array}$ & $\begin{array}{l}\text { Partnerships are most effective when } \\
\text { they are well organised, and all } \\
\text { participants are aware of the } \\
\text { resources/supports available and the } \\
\text { procedures that need to be followed } \\
\text { (Norsen } \text { et al., 1995; Schroeder et al., } \\
\text { 1999; Whitt et al., 2008). }\end{array}$ & $\begin{array}{l}\text { Inclusive partnerships creatively } \\
\text { negotiate how best the range of } \\
\text { resources / supports available can be } \\
\text { optimised to remove possible barriers or } \\
\text { impediments to learning. This may } \\
\text { heighten engagement through creative } \\
\text { solutions. }\end{array}$ \\
\hline $\begin{array}{l}\text { Involve the whole } \\
\text { university }\end{array}$ & $\begin{array}{l}\text { Senior administrators in academic } \\
\text { and student affairs should provide } \\
\text { opportunities for partnership } \\
\text { development (Schroeder et al., 1999; } \\
\text { Whitt et al., 2008; HEA, 2014; } \\
\text { Healey et al., 2014). }\end{array}$ & $\begin{array}{l}\text { The ethos of partnership needs to run } \\
\text { throughout the university in order to be } \\
\text { authentic and meaningful. This develops } \\
\text { trust, which in turn, enhances a sense of } \\
\text { belonging, and the likelihood of } \\
\text { successful and sustained engagement. }\end{array}$ \\
\hline $\begin{array}{l}\text { Embrace challenges to } \\
\text { diversify learning } \\
\text { opportunities }\end{array}$ & $\begin{array}{l}\text { Partnerships, that build trust and } \\
\text { security, may support participants to } \\
\text { take risks, step out of their comfort } \\
\text { zone and try new learning activities } \\
\text { (Schroeder } \text { et al., 1999; HEA, 2014). }\end{array}$ & $\begin{array}{l}\text { Inclusive partnership may encourage } \\
\text { previously disenfranchised students to } \\
\text { take risks with appropriate and } \\
\text { structured support, to be challenged, and } \\
\text { illustrate to staff more creative and } \\
\text { innovative approaches. }\end{array}$ \\
\hline $\begin{array}{l}\text { Maintain a flexible and } \\
\text { open-minded approach to } \\
\text { the partnership and its } \\
\text { outcomes }\end{array}$ & $\begin{array}{l}\text { Partnerships require and enable } \\
\text { institutions and staff to move beyond } \\
\text { rigid interpretations of the curriculum } \\
\text { and creatively fostering flexibility } \\
\text { and an ability to cope with } \\
\text { complexity (Mann, 2001; Waterfield } \\
\text { and West, 2006). }\end{array}$ & $\begin{array}{l}\text { Inclusive partnerships challenge } \\
\text { institutions to re-think hierarchical } \\
\text { regulatory systems and promotes } \\
\text { individual autonomy and creativity. It } \\
\text { facilitates optimal learning by working } \\
\text { with students own intrinsic preferences, } \\
\text { constraints, and aspirations. }\end{array}$ \\
\hline
\end{tabular}

Table 2: Some principles and characteristics of partnership and inclusive partnership 


\begin{tabular}{|c|c|c|c|}
\hline Activity & Learning context & Benefits & Challenges \\
\hline $\begin{array}{l}\text { Collaborative } \\
\text { enquiry-based } \\
\text { learning }\end{array}$ & $\begin{array}{l}\text { - Small groups work together to solve } \\
\text { geographical problem } \\
\text { - } \quad \text { Ideal for formative assessment at early } \\
\text { stage. } \\
\text { - Opportunities for rapid bonding, } \\
\text { experimentation, and exploration. } \\
\text { - Summative assessment might be introduced } \\
\text { later. } \\
\text { - Opportunities to celebrate diversity. }\end{array}$ & $\begin{array}{l}\text { - Opportunity to teach principles of team work } \\
\text { and diversity awareness (increasing student } \\
\text { capacity for inclusive peer relations) } \\
\text { - Learning from others' experiences } \\
\text { - } \quad \text { Students identify own strengths and } \\
\text { weaknesses } \\
\text { - Facilitate multi-disciplinary working } \\
\text { - Core skills development }\end{array}$ & $\begin{array}{l}\text { - Self-selecting group membership can } \\
\text { perpetuate difference although tutor or } \\
\text { arbitrary method can create friction and/or } \\
\text { alienation. } \\
\text { - Team size needs to be manageable. } \\
\text { Assigning roles can help. } \\
\text { It is sometimes hard to break down } \\
\text { deeply embedded prejudices and } \\
\text { stereotypes and the teaching of diversity } \\
\text { awareness needs sensitive handling }\end{array}$ \\
\hline $\begin{array}{l}\text { Inclusive } \\
\text { assessment }\end{array}$ & $\begin{array}{l}\text { Students work toward identical learning } \\
\text { outcomes. } \\
\text { Choice given in content (e.g. topic, scope, } \\
\text { focus), output, and/or structure and timing. } \\
\text { Flexible elements negotiated and agreed } \\
\text { between student and tutor. } \\
\text { Good in field-based investigation, } \\
\text { geography dissertations (e.g. Hill et al., } \\
\text { 2011), portfolio assignments (e.g. } \\
\text { Nicholson, 2011), and research-based final } \\
\text { year modules. }\end{array}$ & $\begin{array}{l}\text { - Allows for focus on interesting and relevant } \\
\text { topics. } \\
\text { Optimises students' learning preferences, } \\
\text { talents, experiences and skills. } \\
\text { Increased motivation and engagement with the } \\
\text { task. }\end{array}$ & $\begin{array}{l}\text { - Needs managing across a programme to } \\
\text { prevent too narrow a discipline focus or } \\
\text { limited range of outputs. } \\
\text { Flexible timing and/or assessment } \\
\text { structure can challenge logistics, } \\
\text { institutional deadlines, and regulations. } \\
\text { Ensuring equivalence in different } \\
\text { products (i.e. that they meet the same } \\
\text { learning outcomes, and are assessed to the } \\
\text { same standard). }\end{array}$ \\
\hline $\begin{array}{l}\text { Creative } \\
\text { outputs for } \\
\text { independent } \\
\text { research } \\
\text { project }\end{array}$ & $\begin{array}{l}\text { - Students conduct independent, individual } \\
\text { geography research project (usually final } \\
\text { year). } \\
\text { - } \quad \text { One-to-one supervision by tutor. } \\
\text { - Substantial student input into topic } \\
\text { selection, research design, and end product } \\
\text { (e.g. Hill et al. } 2011 \text { ). }\end{array}$ & 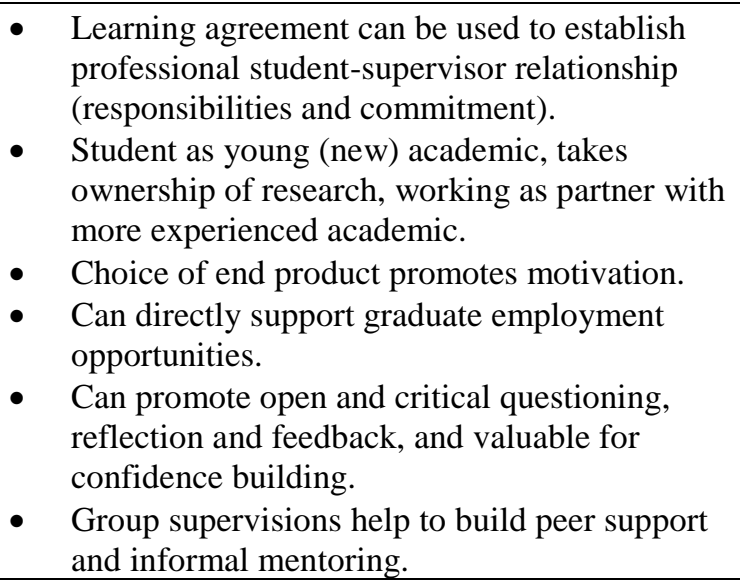 & $\begin{array}{l}\text { Too much choice can be overwhelming } \\
\text { and needs management by supervisor } \\
\text { and/or project leadership team. } \\
\text { One-to-one relationships sometimes go } \\
\text { awry. } \\
\text { Can be elitist where students selected to } \\
\text { participate in tutors' research (e.g. } \\
\text { summer expeditions, bursaries). }\end{array}$ \\
\hline $\begin{array}{l}\text { Expedition } \\
\text { management }\end{array}$ & $\begin{array}{l}\text { - Tutor-led research expeditions common in } \\
\text { geography but semi-selective. }\end{array}$ & $\begin{array}{l}\text { Valuable experience for CV development and } \\
\text { graduate skills. }\end{array}$ & $\begin{array}{l}\text { May lead to a disjuncture between } \\
\text { participants and students who have not } \\
\text { had the opportunity to take part (e.g. }\end{array}$ \\
\hline
\end{tabular}




\begin{tabular}{|c|c|c|c|}
\hline & $\begin{array}{l}\text { For participants, multiple opportunities to } \\
\text { contribute to expedition design, } \\
\text { management and research activity (e.g. } \\
\text { Fuller } \text { et al., 2014). } \\
\text { Can take responsibility for equipment } \\
\text { maintenance, budgeting, provisions, } \\
\text { catering, transport, library. }\end{array}$ & $\begin{array}{l}\text { Opportunities to engage with, contribute to, } \\
\text { and co-author real research and subsequent } \\
\text { outputs. } \\
\text { Opportunities for strong bonding between staff } \\
\text { and students. }\end{array}$ & $\begin{array}{l}\text { relating to culture, finance, academic } \\
\text { standing, carer commitments, medical } \\
\text { condition). }\end{array}$ \\
\hline $\begin{array}{l}\text { Peer } \\
\text { mentoring }\end{array}$ & $\begin{array}{l}\text { A more experienced student cohort } \\
\text { provides one-to-one or group mentoring for } \\
\text { a less experienced cohort. } \\
\text { - Works well in final year geography project } \\
\text { preparation. } \\
\text { Effective in induction activities aimed at } \\
\text { smoothing transition to HE (Richardson } \\
\text { and Tate, 2013). } \\
\text { Mentees and mentors help shape design, } \\
\text { scope and duration of mentorship scheme. }\end{array}$ & $\begin{array}{l}\text { - Mentors benefit from receiving training. } \\
\text { May increase self confidence and self } \\
\text { awareness (e.g. academic skills and emotional } \\
\text { intelligence). } \\
\text { - Develops students' sense of belonging to wider } \\
\text { academic community. } \\
\text { Develops sense of achievement among final } \\
\text { year students. }\end{array}$ & $\begin{array}{l}\text { - Tutor oversight needed to provide quality } \\
\text { assurance. } \\
\text { Final year students may have variable } \\
\text { experiences of supervision that negatively } \\
\text { influence their approach to mentoring } \\
\text { other students. }\end{array}$ \\
\hline $\begin{array}{l}\text { Collaborative } \\
\text { field-based } \\
\text { learning }\end{array}$ & $\begin{array}{l}\text { - Students work in partnership with tutors to } \\
\text { design and/or deliver field-based activities } \\
\text { (e.g. Coe and Smyth, 2010). } \\
\text { Can mirror expedition management style } \\
\text { partnership, or design of one day / } \\
\text { residential fieldwork activities. } \\
\text { Students partner tutors to complete research } \\
\text { design (e.g. suitable sites, research } \\
\text { questions, data collection, field techniques, } \\
\text { equipment). }\end{array}$ & $\begin{array}{l}\text { Increased engagement in tutor-led phase of } \\
\text { field courses. } \\
\text { Progressive development of research skills } \\
\text { from one day field courses, to residential } \\
\text { fieldwork, to independent fieldwork conducted } \\
\text { as part of advanced courses and final year } \\
\text { projects. }\end{array}$ & $\begin{array}{l}\text { - Can be logistically challenging to satisfy } \\
\text { the requirements of multiple student } \\
\text { teams (e.g. transport, equipment, health } \\
\text { and safety, site access). }\end{array}$ \\
\hline $\begin{array}{l}\text { Enquiry-based } \\
\text { practical } \\
\text { activities }\end{array}$ & $\begin{array}{l}\text { Design and conduct practical activities (e.g. } \\
\text { desk-, laboratory-, computer-based } \\
\text { learning). } \\
\text { - Self-study booklets with tutor and/or } \\
\text { demonstrator assistance. } \\
\text { - Students partner tutors to identify and agree } \\
\text { content (e.g. databases for GIS practical, } \\
\text { appropriate lab tests for sediment } \\
\text { description, remotely sensed images for } \\
\text { desk-based inquiry). }\end{array}$ & 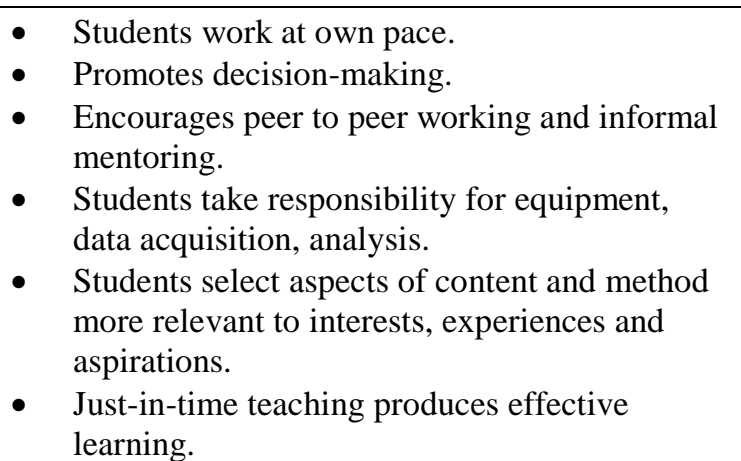 & $\begin{array}{l}\text { - Appropriate preparatory resources } \\
\text { required (e.g. flipped classroom, } \\
\text { techniques manual, online resources and } \\
\text { self-tests, drop-in and catch up sessions). } \\
\text { Can be logistically challenging in a } \\
\text { laboratory situation (e.g. equipment, } \\
\text { samples, health and safety). } \\
\text { Need to ensure basic techniques are all } \\
\text { learned and addressed. }\end{array}$ \\
\hline
\end{tabular}




\begin{tabular}{|c|c|c|c|}
\hline $\begin{array}{l}\text { Work } \\
\text { placement } \\
\text { learning }\end{array}$ & $\begin{array}{l}\text { - Students set up work placements and } \\
\text { associated outputs, or work very closely } \\
\text { with tutors to identify placement } \\
\text { opportunities. }\end{array}$ & $\begin{array}{l}\text { Students work on projects, in locations, and in } \\
\text { organisations, that match their own } \\
\text { employment aspirations, logistical constraints } \\
\text { (e.g. travel from home, costs), and experiences. }\end{array}$ & $\begin{array}{l}\text { Placement tutors have wealth of } \\
\text { knowledge and experience of suitable } \\
\text { placement opportunities and it can be } \\
\text { difficult to release control of placement } \\
\text { choice to the student. }\end{array}$ \\
\hline $\begin{array}{l}\text { Small group } \\
\text { tutorial } \\
\text { learning }\end{array}$ & $\begin{array}{l}\text { Discipline-based content and structure } \\
\text { determined by negotiation and agreement. } \\
\text { Works well in core, skills-based first year } \\
\text { tutorial groups where discipline framework } \\
\text { open to negotiation. }\end{array}$ & $\begin{array}{l}\text { Provides a good opportunity for students and } \\
\text { tutors to identify, discuss and explore their own } \\
\text { discipline-based interests. }\end{array}$ & $\begin{array}{l}\text { - Could disengage individuals who have } \\
\text { less interest in the topic selected by the } \\
\text { group. }\end{array}$ \\
\hline $\begin{array}{l}\text { Engagement } \\
\text { through online } \\
\text { learning }\end{array}$ & $\begin{array}{l}\text { Digital tools used to facilitate inclusive } \\
\text { student-staff and student-student } \\
\text { partnerships. } \\
\text { Online tools include Web 2.0, Virtual } \\
\text { Learning Environments, and social media. } \\
\text { - Can support flipped classroom, extra- } \\
\text { curricular support, and in-class } \\
\text { engagement. } \\
\text { - Students add to curriculum content through } \\
\text { blogging tools, and production and sharing } \\
\text { of media. }\end{array}$ & $\begin{array}{l}\text { - In-class response systems (e.g. Kahoot, } \\
\text { Socrative) to increase engagement. } \\
\text { - Can add to existing content and help shape } \\
\text { future sessions and learning activities. } \\
\text { - Challenging content can be viewed multiple } \\
\text { times and at students' own pace. } \\
\text { Lecture time devoted to more productive, } \\
\text { higher level activities rather than deliver } \\
\text { content. } \\
\text { - } \quad \text { Participants empowered to direct own learning. } \\
\text { - } \text { Dorks well in multi-disciplinary groups. } \\
\text { Develops students' as co-creators of } \\
\text { knowledge. } \\
\text { More up-to-date resources can be made } \\
\text { available. } \\
\text { Lecturer gains from diversity of student input. } \\
\text { Works well in large groups, especially early } \\
\text { stage students, to develop confidence and } \\
\text { autonomy. }\end{array}$ & 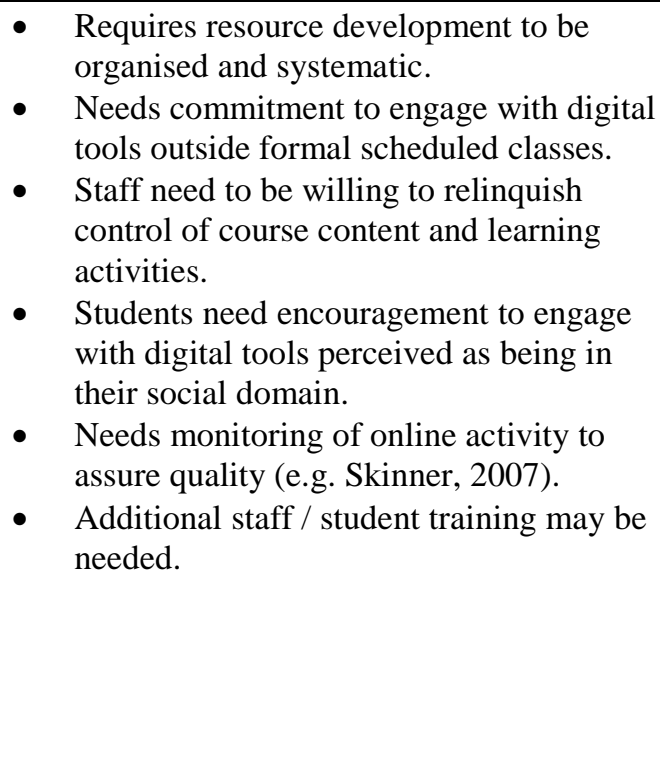 \\
\hline
\end{tabular}

Table 3: Opportunities for embedding inclusive partnership in geography programmes 


\section{List of Figures}

Figure 1: Partnership working in practice

Figure 2 'Selective partnership' versus ‘inclusive partnership' processes 